\title{
Income smoothing practices: Evidence from Egypt
}

Dr. Mohsen Ebied Adelghafar Younis

Faculty of Commerce - Menoufia University

\begin{abstract}
Research objective:

This study examines the existence of income smoothing practices in Egypt and identifies the differences concerning firm characteristics between smoothers and non-smoothers firms.

Design/methodology/approach:

The study uses accidental sample of non-financial firms over the period of 2010-2015 to determine income smoothing index using intelligent software based on Eckel Model. A number of statistical techniques are employed including logistic regression in order to predict the key determinants of income smoothing index.

\section{Findings:}

The study finds prevalence of income smoothing practices in Egyptian firms. In particular, $\mathbf{6 2 . 7 \%}$ are smoothers, while, 37.3\% are non-smoothers. In addition, there are satisfactory differences regarding firm characteristics between prior categories. Logistic regression results reveal that dividend yield, earnings per share, book value, managerial ownership and operating leverage contribute significantly in the prediction of income smoothing behavior.
\end{abstract}

\section{Research scope:}

The paper depends on Egyptian listed firms throughout the period 2010-2015 due to the lack of data. 


\section{Practical implications:}

The study creates new software with beneficial implications for users of financial reports especially financial analysts, shareholders and stakeholders mainly investors as this software merge easily data of income and sales throughout time series in one figure called IS index. Subsequently, created IS index rationalizes comprehensively the decision making process and it provides quick and accurate special reports regarding firms that smooth their income. Unlike prior research that has been computed the income smoothing degree manually.

\section{Originality and importance:}

The study extends the extant literature concerning income smoothing especially in emerging economy. However, it enriches the literature by contributing new computerized methodology that covers the gap concerning difficulty of income smoothing determination.

Keywords: Income smoothing; Non-Smoothers; Firm characteristics; Egypt 


\section{Introduction}

Management of a firm has a widespread scope of selecting from available accounting choices in terms of the recognition, timing or/and accuracy of the transactions, especially, that related to revenues and expenses. Consequently, management may acts intentionally to employ earnings management practices such as income smoothing, manipulation, creative accounting, establishing cookie jar reserves and big bath accounting (Ruch and Taylor, 2015; Plöckinger, et al., 2016). In particular, the practice of smoothing the income is an essential matter in financial accounting because it widely influences the quality of accounting information especially earnings and its ratios. Moreover, users of financial reports generally distrust about the content of these reports. On the other side, income smoothing is a vital feature of earnings management phenomena (Beattie et al., 1994).

Prior empirical research on income smoothing focuses heavily on developed countries such as USA (e.g., Kilic et al., 2013; Michelson, 1995 Christopher, 1988), Canada (e.g., Kanagaretnam et al., 2003), and UK (e.g., Athanasakou et al., 2007; Beattie, 1994). However, little is known in terms of income smoothing practices in developing countries, particularly, Egypt which is an Arabian country in the north of Africa and a hub link between Africa and Asia. Economically, it is a core country in Middle East due to its role in world trade over Sues canal .Moreover, the Egyptian stock market is classified as one of the earlier stock markets in the Middle East as it comprises of Alexandria Stock Exchange and Cairo Stock which had been established in 1883 and 1902, respectively. The Egyptian stock market includes 17 sectors. Thus, it is of prodigious significance to examine the existence of income smoothing throughout firms that belonged to these sectors to provide more protection to investors and other stakeholders. 
There is a slight grasp within Middle East and none of prior research has investigated empirically income smoothing practice in Egypt. Subsequently, the current study extends differently literature undertaking firm characteristics and income smoothing in Egypt for the first time. Accordingly, the study tends to cover this gap in literature. This current study aims to inspect the existence of income smoothing practices in Egypt over a 6-years period from 2010 to 2015. Specifically, the objectives of the current study are two folds. First, it aims to identify the income smoothing degree of firms that are listed in Egyptian stock markets over the period from 2010 to 2015 . Second, the sample is partitioned into two sub-samples; income smoothers sample and non-smoothers sample to identify the differences in firm characteristics between the two sub-samples. Particularly, the study aims at examining the key similarity and dissimilarity in terms of firm characteristics between income smoothers and non-smoother firms. In this context, the study inspects 11 firm characteristics which are mainly profitability, financial leverage, size, liquidity, dividend yield, earnings per share, book value, strategic holding, managerial holding, market value of equity and operating leverage.

This study offers distinct contributions to extant literature in terms of income smoothing throughout several aspects. First, current study presents empirical evidence of income smoothing behavior in Egypt. In addition, it is the first in Egypt to differentiate between characteristics of income smoothing and non-smoothing firms. Third, unlike prior research (e.g., Gaio and Raposo, 2011) that measures earnings smoothing based on earnings and operating cash flow, the current study adopts a new model in order to set key determinants that predict income smoothing. Finally, based on Eckel (1981), the current study develops new accounting software that helps directly in forecasting income smoothing index per firm throughout a specific period. This software can be used widely to classify firms according their income smoothing degree. 
In addition, it is applicable hereafter by different groups of users (e.g., management, investors, financial analysts, creditors, suppliers, shareholders and other stakeholders etc.). In particular, this software is based on time series of data concerning reported income and net sales. It is, also based on changes of income and sales. Subsequently, the coefficient variations per firm or all target firms are derived easily and quickly with high quality of accuracy.

The rest of the study is classified as follow. Section 2 reviews extensively the prior literature of income smoothing in order to evolve and improve hypotheses. Section 3 details research design. The findings of the study are presented in section 4 . Whereas, section 5 presents the conclusions, implications and further research.

\section{Literature review and hypotheses development}

Miscellaneous studies have extensively argued the issue of income smoothing. In earlier study, Eckel (1981) had classified income smoothing to fold types .First, natural smoothing that is done inherently according the firm conditions. Second, intentional smoothing that is appeared as a result of managerial behavior. Intentional smoothing is divided to real and artificial smoothing. In addition, Eckel in his seminal study had proposed that income smoothing occurrence aims at mitigating reported income. In same context, Eckel (1981) attempted to remedy the deficits of previous methodologies related to income smoothing measurement by creating a new proxy of income smoothing based on four postulates which are income is regressed in linear function to sales, consistency of variable costs to sales ratio over time, fixed costs do not decrease and gross sales are subjected in general to be smoothed. However, some figures (e.g., coefficient variation of changes of the each of income and sales etc.) in this seminal study are relatively complicated (Eckel, 1981,p.38). In the same context, Nejad et al. (2013) scrutinized whether income smoothing was 
existed in Iranian companies. They employed Eckel model to detect income smoothing practices through nine annual periods and three types of profits which are net profits, gross profit and operating profits. However, they had censured Eckel methodology as it is not competent to determine all firms which smooth their income. Briefly, their sample comprised of 132 firms and results revealed that nearly $59 \%$ of the sample was classified as smoother firms.

Safdar and Yan (2016) focused on Pakistan stock exchange and found that the majority of firms in Pakistan are classified as smoothers through manipulating accruals. In addition, Yang et al (2012) investigated the influence of corporate governance on income smoothing practices in China and their results revealed that governance mechanisms are inefficient concerning decreasing income smoothing. Furthermore, Khalil and Simon (2014) found that managers control intentionally accruals to mitigate the vacillations of reported earnings. Moreover, Ashari et al.(1994) determined the key factors which enhance income smoothing phenomenon in Singapore especially size, profitability, nationality, industry and operational leverage. They had concluded that the prevalence of income smoothing increases when the companies are less profitability and more risky. In addition, they had detected that Malaysian companies were smoother than Singaporean companies. It is worth nothing that, the findings emphasis on the micro, macro and global incentives of income smoothing. Consistently, Tseng and Lai (2007) attempted to clarify the nature of the relation between income smoothing index and profitability in listed Taiwan firms. Their sample comprised of 147 firms and the results supported the existence of strong negative relationship between profitability and income smoothing. Thus, firms with lower profitability intentionally smooth their income.

Some studies investigate how managerial ownership of a firm could affect the income smoothing practice. For example, Carlson 
and Bathala (1997) have aimed at examining whether the ownership properties affect income smoothing. They had divided their sample which consists of 265 to 172 smoothers and 93 nonsmoothers. Their results revealed that the more insider or institutional ownership percentage was extremely high the more the firm being smoother. The authors found that dispersion of stock ownership had been correlated significantly with income smoothing behavior. Morever, Habib and Jiang (2012) found that managerial ownership entrenches management's control of firms. That is, managerial ownership encourages management empire building as higher managerial ownership provides managers with larger scope causing pragmatic behavior. Hence, managers are extensively engaged in earnings management underlying income smoothing. In contrast, increasing managerial ownership may mitigate the agency theory problems.

Other strand of research focused on economic consequences of income smoothing. For instance, Bitner and Dolan (1996) had found that market value that measured by Tobin's $q$ enhances income smoothing. Consistently, Etemadi and Sepasi (2007) attempted to scrutinize the relation between income smoothing and firm value in Iranian firms. In addition, they have argued the impact of the firm size upon the income smoothing Phenomenon in the sample that comprises of 159 firms. Their results ensured that massive firms have less motivation to smooth income rather than smaller firms. They had replicated the coefficient of variation approach that created by Eckel (1981) with simple modifications. As result of that, they excluded all firms which their coefficients stand between 0.90 and 1.10 as a grey area. Furthermore, Tucker and Zarowin (2006) have argued whether income smoothing amends the informativeness of earning. They utilized a new methodology to measure income smoothing depends on future earning response coefficient. Mahmud (2012) argued that income smoothing was extensively related with industrial sector in Malaysia. The 
sample included 84 firms of non-financial firms. The results indicated that almost $62 \%$ of firms in the sample were stratified as smoothers.

Earlier, Chaney and Jeter (1997) have focused directly on firm characteristics and income smoothing and provided evidence that non- smoothers are smaller and have slighter discretionary accruals. However, crucial divergence between this work and current study can be explicated throughout 3 reasons. First, methodology of income smoothing following Chaney and Jeter (1997) based on outcome approach and behavior approach but current study employs Eckel methodology and creates new software that facilitates its application. Second, sample in the work of Chaney and Jeter (1997) is divided according firm characteristic then examining the extent of income smoothing conversely current study divides sample to smoothers and non- smoothers according income smoothing index then examining similarity and dissimilarity of firm characterisitics. Third, even in logistic regression current study utilizes additional variables not found in that study such as managerial ownership, strategic ownership and book value.

Extant accounting research includes numerous studies concerning the impact of firm size on income smoothing practices. For example, Mahmud ,(2012); Ashari et al.(1994); Bora and Saha,2016) refer to affirmative relation between income smoothing existence and firm size due to larger firms are exposed to superior community scan from investors, analysts and other stakeholders. Otherwise, several studies refer that profitability is an incentive to income smoothing incidence. For example, (Ashari et al., 1994; Tseng and Lai, 2007) point out that income smoothing occurrence is correlated negatively with profitability. Accordingly, firms with higher level of profitability have lower motivation to practice income smoothing.

Mahammadi et al. (2012) inspected the connection between cash holding and income smoothing in Iranian firms which listed in 
Tehran Stock Exchange during six annual periods. They demonstrated the key theories which stand behind the cash holding levels. The sample comprehended 73 firms. The results ensured the prevalence of satisfactory and significant linkage between cash holding and income smoothing.

In dissimilarity, Saringat et al. (2013) inspected the existence of income smoothing in a different type of firms which called Shariah compliant firms in Malaysian Capital Market through five annual periods. Eckel model had processed to measure income smoothing degree by using a sample which consisted of 588 firms. Due to this, their results concluded that almost $53.6 \%$ of the firms had exercised income smoothing.

In addition, Rusmin et al. (2013) scrutinized whether income smoothing attitude was practiced in conveyance firms in seven which are China, Hong Kong, India, Japan, Malaysia and Singapore. They used a sample that comprises of 328 firms along four annual periods. Moreover, they had determined several key factors that may cause occurrence of income smoothing such as audit quality, economic crisis and firm size. Results indicated that executive managers have great incentive to smooth reported income downward and upward to meet the target standard income. They also concluded that only economic crisis and firm size actually affected income smoothing.

In sum, prior accounting research related to income smoothing has discussed firm characteristics separately or together in order to clarify its relationship with income smoothing practices. I expect that there are key differences of firm characteristics between smoothers and non-smoothers and firm characteristics may predict income smoothing index in Egypt. According the prior discussions, the following hypothesis is developed: 
Ha: Firm characteristics are significantly different between income smoothers and non-smoothers firms in Egypt

The current study focuses on 11 firm characteristics that are profitability, financial leverage, size, liquidity, dividend yield, earnings per share, book value, strategic holding, managerial holding, market value of equity and operating leverage. Those characteristics are identified as determinants of income smoothing practice in prior research (e.g., Bora and Saha,2016; Habib and Jiang 2012; Tseng and Lai ,2007), therefore, the following sub-hypotheses are developed:

Ha1: Book value is significantly different between smoother and non-smoothers in Egypt.

Ha2: Operating leverage is significantly different between smoother and non-smoothers in Egypt.

Ha3: Financial leverage is significantly different between smoother and non-smoothers in Egypt.

Ha4: Managerial ownership is significantly different between smoother and non-smoothers in Egypt.

Ha5: Firm size is significantly different between smoother and non-smoothers in Egypt.

Ha6: Strategic holding is significantly different between smoother and non-smoothers in Egypt.

Ha7: Profitability is significantly different between smoother and non-smoothers in Egypt.

Ha8: Earning per share is significantly different between smoother and non-smoothers in Egypt.

Ha9: Dividend yield is significantly different between smoother and non-smoothers in Egypt. 
Ha10: Liquidity is significantly different between smoother and non-smoothers in Egypt.

Ha11: Market value of equity is significantly different between smoother and non-smoothers in Egypt.

On another hand, the study aims precisely to scrutinize the influence of firm characteristics on income smoothing degree. So the second main hypothesis is proposed as follow:

Ha2: Firm characteristics impact significantly income smoothing index in Egypt.

\section{Research design}

\subsection{Sample selection and data collection}

The initial sample of study consists of all 229 firms listed in Egyptian Exchange throughout the period 2010-2015. Financial institutions especially banks and insurance companies are excluded because of their special nature, laws and regulations. In addition, firms of missing data regarding income, sales and assets separately or together through the study's period are excluded. Panel A Table (1) shows initial and final size of the study's period. As can be shown, the final size of the sample comprises of 143 firms (858 firm-year observations) which represent $62.4 \%$ of the total listed firms in the Egyptian stock market. With the benefit of hind sight, this percentage is sufficient to continue the research point. In addition, Panels $B$ and $C$ of Table (1) present the sample firms sorted by years and industries, respectively.

\section{<Insert Table (1) about here>}

All financial data are collected from DataStream database according the following codes. Net income (WC01651), sales (WC01001), profitability (WC08301), financial leverage (WC08231), liquidity (WC08106), total assets (WC02999), dividend yield (DY), earnings per share (EPS), book value (WC05476), market value of eq- 
uity(WC08001), strategic holding (NOSHST),managerial ownership (NOSHCO) and depreciation and amortization (WC01151).

\subsection{Empirical model and variables measurements}

Following Eckel (1981), the study measures income smoothing index by quotient of vacillation coefficient of income to vacillation coefficient of sales. A firm is assorted as an income smoother when it has a value less than one and, conversely, it is classified as nonsmoother firm when the value greater than one. Additionally, the study utilizes 11 autonomous variables regarding firm characteristics. Firm size is assessed by logarithm of total assets. Financial leverage is scaled by long term debts, short term debts and a portion of long term debts divided to common equity. Operating leverage is standardized by depreciation and amortization expense divided to total assets. Dividend yield is gauged by dividend per share as a percentage of share prices. Liquidity is measured by quotient of current assets to current liabilities. Earnings per share are taped by the quotient of net income after preferred dividends to year end outstanding shares. Book value is measured by the quotient of book value to outstanding shares. Market value of equity is measured by the logarithm of market capitalization. Profitability is standardized by return on assets. Strategic holding is the percentage of strategic share holdings of $5 \%$ or more. Eventually, managerial holding is measured by percentage of managerial ownership. Therefore, the following logistic regression model is used in order to examine how firm characteristics impact income smoothing index.

$$
\begin{aligned}
\operatorname{Logit}(\mathrm{P}) & =\beta_{0}+\beta_{1} \mathrm{DY}+\beta_{2} \text { EPS }+\beta_{3} \mathrm{BV}+\beta_{4} \mathrm{SH}+\beta_{5} \text { MO } \\
& +\beta_{6} \text { LIQ. }+\beta_{7} \text { PROF. }+\beta_{8} \text { FL }+\beta_{9} \text { SIZE }+\beta_{10} \text { OL } \\
& +\beta_{11} \text { MVE }+\varepsilon_{i t}
\end{aligned}
$$


Where:

$\beta_{0} \quad$ The regression intercept

$\beta_{1} \ldots \beta_{11}$ The regression coefficients

$\varepsilon_{\text {it }}$

The error term

Logit transformation is logistic function and refers to odds ratio. $P$ is the probability of income smoothing. The definitions and measurements of all variables are summarized in Table (2).

<Insert Table (2) about here>

\section{Empirical results and discussion}

\subsection{Descriptive statistics}

Table (3) shows the main descriptive statistics of all variables. Panel A shows the descriptive for all sample firms. While, Panels $A$ and $B$ reports the means and standard deviation in terms of firm characteristics for income smoothers and non-smoothers samples, respectively. Panels $\mathrm{A}, \mathrm{B} \& \mathrm{C}$ reveal that observations of three samples total sample, smoothers' sample and non- smoothers' sample are 858, 372 and 486 individually. That is, the smoother firms are approximately $43.3 \%$ of the total sample. This major result emphasized the notion of income smoothing occurrence in Egypt. This is relatively compatible with previous study by Ashari et al (1994) in Singapore regarding the controversy and continuous phenomena of income smoothing.

Regarding to dividend yield, Panels $B$ \& $C$ report that the mean values are 3.5 and 2.7 respectively. That is, smoother firms control intentionally dividend policy further than non-smoothers. Furthermore, Panels B \& $\mathrm{C}$ indicate that the mean value of strategic holding ratio in smoothers and non-smoothers are $41.4 \%$ and 36.9\% individually. In same line, These Panels show that the mean value of managerial ownership percentage in smoothers $(\mathbf{1 5 . 7 \%})$ is greater than the mean value in non-smoothers $(\mathbf{1 0 . 8 \%})$. That is, management's actions stand as preliminary determinants 
of income smoothing practices. This is similar with the findings which reported in prior research (e.g., Fudenburg \& Tirole, 1995; Koh, 2007; Habib \& Jiang, 2012).

Otherwise, descriptive statistics in Panels B \& $\mathrm{C}$ show that the mean value of profitability in smoothers and non-smoothers is 0.8\% and $4.3 \%$ separately. Namely, firms with lower profitability ratios have larger motivations and incentives to smooth reported earnings than firms with higher ratios of profitability. This is relatively consistent with prior research (Tseng \& Lai, 2007).

<Insert Table (3) about here>

\subsection{Considerations of the analysis}

Basically, determination of statistical techniques relies on the data measurement level, number and size of samples, and shape of normal distribution. In current study these constraints are considered. First, I used Kolmogorov-Smirnov test to explore the normality distribution of data. The results of KolmogorovSmirnov test are reported in Table (4) which shows that all variables are significant at .01 significant levels. Therefore, the results suggest an absence of normal distribution. Thus, Non-parametric tests are employed in this study. Second, the study's sample comprises of two independent samples smoothers and non-smoothers. Hence, Mann-Whitney test is the suitable test to examine the first hypothesis concerning firm characteristics. This is consistent with some extant research (e.g., Bora \& Saha, 2016).

<Insert Table (4) about here>

As can be seen in Table (4), all significance values according Kolmogrov-Smirnov $^{1}$ are less than $5 \%$.That is, candidate variables do not follow the normal distribution. Potential cause of this devia-

1 - Significance less than $5 \%$ refers to the absence of normality .Consequently, non- parametric tests are employed.Otherwise, variables follow normal distribution and parametric tests are used. 
tion is huge diversity among Egyptian listed firm along several aspects such as firm size and risk exposure. In addition, the study replicated the method reported by Eckel (1981) in order to determine the income smoothing degree by using the data of listed firms throughout period 2010-2015. I excluded any company of missing data of income, sales, earnings and assets or other firm characteristics individually or together. Also, financial institutions (e.g., banks and insurance companies etc.) are excluded because of their special nature and legislations.

\subsection{Firm characteristics significant differences}

Table (5) shows the results of Mann-Whitney test concerning key differences of firm characteristics between smoothers and nonsmoothers. In terms of book value, result refers to the existence of significant divergence between to sub-samples smoothers and nonsmoothers as significance value is less than $5 \%$ and the means rank for sub-samples are 413.68 and 477.90 respectively. Possible explication is that firms with smaller book value are motivated to smooth their reported income. Vice versa, firms with greater book value do not need to smooth their income especially these firms are exposure to scan by analysts, investors and public unions.

Likewise, the significance values of operating leverage and financial leverage are .000 and $\mathbf{. 0 0 3}$ individually. That is, there is satisfactory diversity between smoothers and non- smoothers related to types of leverage. Comparatively, the mean rank values of operating and financial leverage in non- smoothers are 483.59 and 472.36 which are greater than the mean rank amounts in sample of smoothers which are 406.04 and 421.13 separately. Namely, types of leverage are key determinants of income smoothing in Egyptian stock market. Potential commentary is that risk exposure may enhance firms to smooth their reported earnings.

On the same context, the significance value concerning total assets as proxy of firm size equals $\mathbf{. 0 2 9}$ and the mean rank values through sample of smoothers and sample of non-smoothers are 
428.56 and 466.82, respectively. This is relatively consistent with prior study by Etemadi and Sepasi (2007) who conclude that the firm size impacts significantly the presence of income smoothing practices .Possible explanation is firms with larger sizes are exposed to scan by several types of stakeholders analysts, auditors, governmental devices and unions, Thus, these firms less managing reported earnings than firms with slighter sizes.

In terms of strategic holding and managerial ownership, the significance values are .044 and .015 respectively. Whereas, the mean rank amounts of these items in sample of smoothers are 470.01 and 471.93 correspondingly. Conversely, the mean rank values of the same characteristics in the sample of non-smoother are lower than as the values of mean are 435.98 and 434.55 individually. That is, strategic holding and managerial ownership are key factors that affect the income smoothing occurrence in Egypt. Potential demonstration is when managerial ownership increases management empire building raises. Thus, opportunistic behavior of management may encourage manipulating reported income. This is relatively similar with the preceding work by (Habib and Jiang, 2012).

On contrary, Panel (B) of Table (5) reports that there are five additional characteristics are insignificant which are dividend yield, earnings per share, liquidity, profitability and market value of equity. Although, there is no a satisfactory difference in profitability between two categories smoothers and non- smoothers, the relationship between income smoothing and profitability is negative. This recent conclusion is compatible with the results of study by (Tseng \& Lai, 2007). Possible explication is firms that realize higher profitability do not need to smooth their income and vice versa firms with lower profitability are accelerated to smooth their reported income.

Moreover, as shown in Panel (B), there was not a satisfactory diversity between listed firms concerning profitability, earnings per share, dividend yield and market value of shares. That is, these 
firm characteristics do not differentiate clearly across smoother and non-smoother firms. However, this conclusion especially regarding market value of shares is conflicting with prior results reported by (Bitner \& Dolan, 1996).It is not surprising because of inefficiency of Egyptian market besides the diversity of legislation and organizational rules between this market and other stock markets.

\section{<Insert Table (5) about here>}

\subsection{Empirical results}

Binary logistic regression is employed because income smoothing index behaves as a dichotomous variable for smoothers and nonsmoothers. Table (6) reports preliminary results of the Binary logistic regression from the $\mathbf{1 1}$ firm characteristics are examined to foresee the probability of income smoothing. As can be shown in Table (6),the results revealed that operating leverage, book value, dividend yield and managerial ownership are extremely high significant in anticipating income smoothing phenomena in Egypt. To conclude, these characteristics are classified as key factors in the process of income smoothing prediction.

\section{< Insert Table (6) about here>}

On contrary, results reported in Table (6) indicates that earnings per share and market value of equity do not contribute significantly in predicting the probability of income smoothing in Egypt. Accordingly, I could establish logistic regression model according prior empirical results as follow:

$$
\begin{aligned}
\text { Logit }(p)= & -.042-0.044 *(\text { D Y })-0.025 *(\text { EPS })-.016 *(B V)+ \\
& .050 *(\text { M O })+16.611 *(\text { OL })
\end{aligned}
$$

\section{Concluding remarks}

The study is the first to investigate empirically the significant divergence of firm characteristics between smoothers and nonsmoothers in Egyptian Exchange. Particularly, this study aims at examining the influence of firm characteristics on the probability 
of income smoothing. The study replicates the method that reported by Eckel (1981) to measure income smoothing index. However, the study creates to the best of my knowledge new accounting software based on Eckel methodology in order to facilitate the process of income smoothing detection.

It is worth nothing that, this software will be useful for internal and external users of financial reports especially other stakeholders such financial analysts, investors, governmental devices and other related parties. Thus, the importance of this software can be explicated by its accuracy, quality of reports, saving effort and cost, timeliness and avoiding huge sophistications regarding sum of income smoothing index manually.

The study depended on non-parametric tests especially MannWhitney and developed binary logistic regression by using data of listed firms in Egyptian stock market. The empirical results reveal that there is significant difference between smoothers and nonsmoothers regarding firm characteristics especially managerial ownership, strategic holding, book value, firm size, operating leverage and financial leverage. However, no significant difference appears between smoothers and non-smoothers particularly concerning profitability, earnings per share, dividend yield, liquidity and market value. Overall, the results reinforce incompletely the first hypothesis.

The empirical results regarding logistic regression indicate that dividend yield, book value, managerial ownership and operating leverage affect significantly the income smoothing index. However, no significant impact is detected relatively to earning per share. The findings of study contribute to accounting literature through helping the users of annuals reports to stratify firms according the income smoothing degree. However, these findings can be used easily and practically as obligatory requirement of registration.

The study's proposed software has beneficial implications for users of financial reports such financial analysts, shareholders and 
others categories of stakeholders mainly investors because this software merge easily data of income and sales throughout time series in one figure called IS index. It is north nothing that, supposed IS index will support comprehensively the decision making process of users. Also, this software provides extensively quick and accurate special reports of firms separately or together.

However, the study is surrounded by some limitations that have to be speculated as possible opportunities for further research. First, the study employed just only one proxy that known by Eckel method to measure income smoothing degree. Subsequently, the related software is limited by this method. It is will be valuable to extend this point by creating overall software that measures comprehensively income smoothing index according different methodologies involved in the extant accounting literature. Second, results of current study are derived from Egyptian environment throughout critical period with its special economic, social, political, cultural, legal characteristics. Therefore, extending the current research design by adding other countries with different conditions may be plausible intuition of future research. This may help in detecting additional determinants that impact significantly income smoothing occurrence. Third, the current study's logistic regression model based on 11 firm characteristics and it is exposed to improve as a conjecture of future research. 


\section{REFERENCES}

Ashari,N., Koh , H. C.,Tan, S. L. and Wong, W. H. (1994),"Factors affecting income smoothing among listed companies in Singapore", Accounting and business research,Vol.24,No.96, pp.291-301.

Athanasakou, V. E., Strong, N. C. and Walker, M. (2007), "Classificatory income smoothing: The impact of a change in regime of reporting financial performance", Journal of Accounting and Public Policy, Vol. 26, No.4, pp.387-435.

Beattie, V., Brown, S., Ewers, D., John, B., Manson, S., Thomas, D. and Turner, M. (1994), "Extraordinary items and income smoothing: A positive accounting approach", Journal of Business Finance \& Accounting, Vol.21, No.6, pp. 791811

Bitner , L. N. and Dolan, R. C.(1996)," Assessing the relationship between income smoothing and the value of the firm", Quarterly Journal of Business and Economics, pp.16-35.

Bora, J. and Saha, A. (2016), "Investigation on the Presence of Income Smoothing Among NSE-Listed Companies", IUP Journal of Accounting Research \& Audit Practices, Vol.15, No.1, pp.55-72.

Carlson, S. J. and Bathala, C. T. (1997)," Ownership differences and firms' income smoothing behavior" Journal of Business Finance \& Accounting, Vol. 24, No.2, pp. 179-196.

Chaney, P. K. and Jeter, D. C. (1997), Income Smoothing Firm Characteristics, Accounting Enquiries, Vol. 7, pp.1-50.

Eckel, N. (1981)," The income smoothing hypothesis revisited", Abacus, Vol.17, No.1, pp. 28-40. 
Etemadi, H. and Sepasi, S. (2007),"A Relationship between Income Smoothing Practices and Firms Value in Iran", Iranian Economic Review, Vol.13,No.20, pp.25-42.

Fudenberg, D. and Tirole, J. (1995)," A theory of income and dividend smoothing based on incumbency rents", Journal of Political economy, Vol.103, No.1, pp.75-93.

Gaio, C.and Raposo, C. (2011), "Earnings quality and firm valuation: international evidence", Accounting \& Finance, Vol.51, No.2, pp.467-499.

Habib, A. and Jiang, H. (2012)," Managerial ownership-induced income smoothing and information asymmetry", Pacific Accounting Review, Vol. 24 , No. 2 , pp.211-232.

Khalil, M. and Simon, J. (2014),"Efficient contracting, earnings smoothing and managerial accounting discretion", Journal of Applied Accounting Research,Vol.15, No.1, pp. 100-123.

Kilic, E. , Lobo, G.J. , Ranasinghe ,T. and Sivaramakrishnan, K. (2013), " The impact of SFAS 133 on income smoothing by banks through loan loss provisions ",The Accounting Review, Vol. 88 ,No. 1, pp. 233-260.

Koh, P. S. (2005), "Institutional ownership and income smoothing: Australian evidence".Accounting Research Journal, Vol.18, No.2, pp.93-110.

Mahmud, N.M.(2012), "Income smoothing and industrial sector", Finance Management, Vol.50, pp.10248-10252.

Michelson, S. E., Jordan-Wagner, J. and Wootton, C. W. (1995), "A market based analysis of income smoothing", Journal of Business Finance and Accounting, Vol.22,No.8, pp.11791193.

Mohammadi, S., Maharlouie, M. M. and Mansouri, O. (2012), "The effect of cash holdings on income smoothing", Inter- 
disciplinary Journal of Contemporary Research in Business, Vol.4, No.2, p. 523.

Nejad, H. S., Zeynali, S. and Alavi, S. S. (2013). Investigation of income smoothing at the companies listed on the stock exchange by using index Eckel (case study:Tehran stock exchange). Asian journal of management sciences and education. Vol.2 ,No.2, pp.49-62.

Plöckinger, M., Aschauer, E., Hiebl, M. R. and Rohatschek, R. (2016), "The influence of individual executives on corporate financial reporting: A review and outlook from the perspective of upper echelons theory", Forthcoming in the Journal of Accounting Literature, Vol.37, pp.55-75.

Ruch, G. W. and Taylor, G. (2015)," Accounting conservatism: A review of the literature" Journal of Accounting Literature, Vol.34, No.17-38.

Rusmin, R., Scully, G. and Tower, G. (2012)," Income smoothing behaviour by Asian transportation firms", Managerial Auditing Journal, Vol.28,No.1, pp.23-44.

Safdar, R., Safdar, R., Yan, C. and Yan, C. (2016),"Managing accruals for income smoothing: empirical evidence from Pakistan",Journal of Accounting in Emerging Economies, Vol.6, No. 4, pp.372-387.

Saringat, S. M., Haron, R. and Tahir, H. H. M. (2013),"Income smoothing and Islam: an evidence from Malaysian Shariah compliant companies", International Journal of Social Science and Humanity, Vol.3, No. 2, pp.160.162

Shubita, M. F. (2015), "The impact of income smoothing on earnings quality in emerging markets: Evidence from GCC markets", Journal of Accounting in Emerging Economies, Vol. 5,No.3, pp.299-324. 
Tseng, L.J. and Lai, C. W. (2007),"The relationship between income smoothing and company profitability: An empirical study", International Journal of Management, Vol. 24,No.4, pp.727-733.

Tucker, J. W. and Zarowin, P. A. (2006), "Does income smoothing improve earnings informativeness?", The Accounting Review, Vol.81,No.1, pp. 251-270.

Yang, C. Y., Leing Tan, B. and Ding, X. (2012)," Corporate governance and income smoothing in China", Journal of Financial Reporting and Accounting, Vol.10, No.2, pp.120139.

Yang, C. Y., Murinde, V. and Ding, X. (2008)," Ownership Structure, Corporate Governance and Income Smoothing in China", Working Paper, Department of Business, Economics \& Management, Xi'an Jiaotong-Liverpool, China, 1, p. 28 